\title{
Retraction Note: Forearm Bone Mineral Density in Postmenopausal Women with Rheumatoid Arthritis
}

\author{
J. Iwamoto ${ }^{1} \cdot$ T. Takeda $^{1} \cdot$ S. Ichimura ${ }^{2}$
}

Published online: 19 November 2019

○) Springer Science+Business Media, LLC, part of Springer Nature 2019

Retraction Note: Calcified Tissue International (2002) 70:1-8
https://doi.org/10.1007/s00223-001-1054-6

The Editors-in-Chief have retracted this article [1]. Serious concerns have been raised about the data presented [2], and after careful consideration and additional investigation the Editors-in-Chief no longer have confidence in this article.

All authors were contacted and did not respond to correspondence about this retraction.

\section{References}

1. Iwamoto J, Takeda T, Ichimura S (2002) Forearm bone mineral density in postmenopausal women with rheumatoid arthritis. Calcif Tissue Int 70:1-8. https://doi.org/10.1007/s00223-001-1054-6
2. Bolland MJ, Avenell A, Gamble GD, Grey A (2016) Systematic review and statistical analysis of the integrity of 33 randomized controlled trials. Neurology 87:2391-2402. https://doi. org/10.1212/WNL.0000000000003387

Publisher's Note Springer Nature remains neutral with regard to jurisdictional claims in published maps and institutional affiliations.

The original article can be found online at https://doi.org/10.1007/ s00223-001-1054-6.

J. Iwamoto

jiwamoto@sonata.plala.or.jp

1 Department of Sports Medicine, Keio University School of Medicine, 35 Shinanomachi, Shinjuku-ku, Tokyo 160-8582, Japan

2 Department of Orthopedic Surgery, National Defense Medical College, 3-2 Namiki, Tokorozawa, Tokorozawa, Saitama 359-8513, Japan 